\title{
FULLFILLMENT OF DISABILITY RIGHTS BASED ON DEFINITIONS, LEGAL BASIS, CRITERIA, AND AIMS OF INCLUSIVE EDUCATION IN INDONESIA
}

\author{
Gardiana Karya1', Insiatun2 Nindya Ayu Rizqianti³, Putri Kartika Ningsih4, Ediyanto ${ }^{*}$, Asep \\ Sunandar6, Dzintra Iliško7, \\ 1,2,3,4,5,6 Universitas Negeri Malang, Malang, Indonesia \\ ${ }^{7}$ Center of Sustainable Education of Daugavpils University, Daugavpils, Latvia \\ *ediyanto.fip@um.ac.id
}

\begin{tabular}{|c|c|}
\hline Article Info & ABSTRACT \\
\hline $\begin{array}{l}\text { Article history } \\
\text { Received May 6, } 2021 \\
\text { Revised June 11, 2021 } \\
\text { Accepted June 19.2021 }\end{array}$ & \multirow[b]{2}{*}{$\begin{array}{l}\text { One of the Indonesian government's efforts to provide equal } \\
\text { education for disabilities is by implementing inclusive } \\
\text { education. Inclusive education gives special needs (SEN) } \\
\text { students have the same opportunity to get education } \\
\text { together in class with the typical students of their age and } \\
\text { obtain equal education services. So, inclusive education } \\
\text { concept understanding is needed to provide information } \\
\text { about inclusive education. Therefore, this article's } \\
\text { arrangement provides information about inclusive education's } \\
\text { definition, legal basis, characteristics, and aims. The current } \\
\text { study method used a literature review of five books and l7 } \\
\text { articles. It showed that inclusive education is the education } \\
\text { service given to the unique needs students to have equal } \\
\text { opportunity to school in the regular school and obtain equal } \\
\text { service. The implementation of inclusive education had been } \\
\text { regulating by international regulations and, in more detail, } \\
\text { regulated by Indonesian government regulations. The } \\
\text { characteristics of inclusive education must consider the } \\
\text { interests of the disabilities and their flexibility to create an } \\
\text { education that could run well and lasts long. In addition to } \\
\text { imposing equal educational rights without any differentiation } \\
\text { and optimizing special needs students' potential, inclusive } \\
\text { education could also increase the interaction of special } \\
\text { needs students. }\end{array}$} \\
\hline $\begin{array}{l}\text { Keywords: Disability rights; } \\
\text { Inclusive Education, Indonesia }\end{array}$ & \\
\hline
\end{tabular}

\section{INTRODUCTION}

Obtaining an education is the right of all Indonesian citizens, and without exception, children with disabilities. The right to obtain an education is stated in the Law of the Republic of Indonesia number 20 of 2003 concerning the national education system by the Ministry of National Education. One of the fulfillment of children's education rights with special needs is by providing inclusive education service. Inclusive education is equalizing educational services for special needs children with typical children (Engelbrecht et al., 2017; Handayani \& Rahadian, 2013; Herawati, 2016). Inclusive education aims to provide the broadest possible opportunities for all special needs students to obtain quality education based on their needs and create education that respects diversity and does not discriminate against them. 
The regulation of inclusive education implementation had been prepared in such a way, in both international and national regulations. The United Nations issued the declaration on Human Rights that guarantees everyone has the right to education to play a full role in society (Handayani, \& Rahadian, 2013). The concept of government policy about inclusive education is the right of all citizens, including persons with disabilities and disabled persons, guaranteed by the Constitution of 1945, Article 31, Section 1, which stated that every citizen has the right to education. Juridical and empirical foundations of inclusive education are applied based on Constituent of 1945, Act No.4 of 1997 on Persons with Disabilities, Act No. 39 of 1999 on Human Rights, Act No. 23 of 2002 on Child Protection, Act No. 20 of 2003 on National Education System, Government Regulation No. 19 of 2005 on National Education Standards (Saputra, 2016).

The implementation of inclusive education in Indonesia has not been optimal. University students with disabilities think that segregation education is better than inclusive education because the needs of the special needs children can be fulfilled (Triutari, 2014). The disability university students stated that inclusive school had not met the needs of children with disabilities because it is still new and has not been adequately implemented (Triutari, 2014). Inclusive education was implemented by the government and related parties, but the executor did not have a deeper understanding of inclusive education. So, there is a need for knowing and learning the characteristics of inclusive education.

On the other hand, the Indonesian government has made preparations to achieve the aim of inclusive education. Inclusive education policy aims to obtain education for children with disabilities equal to normal children. The applied inclusiveness values can introduce children to how to appreciate differences and diversity in school. The implementation of an inclusion program can foster the social skills and confidence of the children. An inclusive education program allows children to interact, communicate, and adapt to society (Dewi, 2017). The inclusive school aims to give all students opportunities to optimize their potential and fulfill their learning needs through the inclusive education program. Inclusive education is an education program that accommodates all students in the same class based on their age and development (Tarnoto, 2016).

Therefore, Based on the background analysis, it is necessary to do an in-depth literature review needs to be carried out to provide essential information about the basic concept of inclusive education and where the problem position or policy problem is concerning disability rights. This article will answer several questions, which are: 1) What is the definition of inclusive education in Indonesia?; 2) What is the legal basis of inclusive education in Indonesia?; 3) What are the characteristics of inclusive education in Indonesia?; and 4) What are the objectives of inclusive education in Indonesia? 


\section{METHODS}

The research method applied in this study is a literature review to achieve the objectives of the study. A literature review is carried out by sorting and selecting peer-reviewed journal articles published from 2010 to 2021. The steps used in this study are selecting keywords according to the research questions related to the basic concepts of inclusive education. According to Gasparyan, Ayvazyan, Blackmore, \& Kitas (2011), literature review (narrative review) has three steps, and there are define the scope (on the introduction part), article selection, and writing the result.

\subsection{Articles Selection}

The researcher used the article selection to find each of the topics discussed in this study. The first problem is the definition of inclusive education. The articles searched on Google with the keyword "Definition of inclusive education" published from 2010 to 2021 and found 15.600 articles. Furthermore, in the screening stage where articles were selected based on relevant articles and found 2.030 articles. The second problem is related to inclusive education's legal basis, and the search on Google Scholar found 2.970 articles. Then, those articles were sorted based on relevant discussion and found 233 articles. Third, the articles search on google scholar http://www. scholar.google.co.id/ with the keyword "Characteristics of Inclusive Education" and found 26.600 articles. There are 15.100 articles found after sorting articles with the range of publication around 2010 to 2021. The fourth formulation problem is related to the aim of inclusive education. The keyword search on Google scholar was "Inclusive Education Goals," with a range of articles published from 2010 to 2021 and found 42.600 articles. Furthermore, those articles were sorted based on relevant articles and found 2.000 articles.

\subsection{Analysis of the Study}

The researcher carried out the literature review by utilizing the evidence-informed approach from the articles and books, three national books, two international books, 12 national papers, and five international papers. After finding literature works, the researchers analyzed the data by analyzing the literature based on each topic. The first formulation problems related to inclusive education used three national articles and two international articles. The second formulation problem is the legal basis of inclusive education, which used three national papers and one international paper. The third formulation problem is related to inclusive education characteristics used two national books, two international books, two national journal articles, and two international journal articles. The fourth formulation problem used four articles which consist of 4 articles. 


\subsection{Articles Categorization}

The researchers' books and articles can answer the questions that arise and the topic discussions related to the definition, legal basis, characteristics, and aims of inclusive education.

\section{RESULTS AND DISCUSSION}

\subsection{Definition of Inclusive Education}

The literature study found that the definition of inclusive education raises the quality of education and placement issues and, more importantly, focuses on social justice (Miles, \& Singal, 2010). Inclusive education is access to education, acceptance, participation, and the promise of quality education for all (Engelbrecht, Savolainen, Nel, Koskela, \& Okkolin, 2017). Inclusive education is the education for all, including children with special needs to join the regular classes and children who experience learning barriers. Those learning barriers include geographical conditions, socioeconomic and cultural factors, and students at risk of dropping out because of disaster, conflict, experiencing sexual abuse and pregnancy, disease susceptibility, and also infection by HIV/ AIDS (Handayani \& Rahadian, 2013).

Inclusive education is the education service system that allows special needs children to study with typical children in public schools near their living place. The spirit of inclusive education implementation provides opportunities or most comprehensive access to all students to obtain quality education and appropriate individual needs without discrimination (Herawati, 2016). Inclusive education is the implementation education system that provides opportunities to the students who have disabilities and intellectual potential or unique talents to participate in education with other normal children in one environment (Miles \& Singal, 2010; Engelbrecht, Savolainen, Nel, Koskela, \& Okkolin, 2017; Permendiknas, 2015; Herawati, 2016; Handayani \& Rahadian, 2013).

Inclusive education is one of the government's commitments to providing the right to education for special needs children. There is a slight difference between inclusive education related to special needs children and children with learning barriers (Handayani \& Rahadian, 2013). Still, the rights to education apply to all Indonesians in line with the Constituent of 1945 , Article 31, Section 1 and 2. In accepting special needs children, consider the distance between school and students' living place (Herawati, 2016), such as the public schools that applied a zoning system in accepting new students. 


\subsection{Legal Basis of Inclusive Education}

The literature result showed many legal bases of inclusive education in Indonesia based on the Act and government regulation to provide the most comprehensive opportunities for Indonesian citizens (Rama, 2012). The United Nations issued a declaration of Human Rights that guarantees everyone's right to obtain proper education so that they can play a full role in society (Handayani \& Rahadian, 2013).

In supporting and increasing Indonesian students' participation in attending school, the Government of Indonesia enacted the Republic of Indonesia No. 20 of 2003 on the National Education System. The Act mentioned the implementation of special education. Article 2 stated that citizens whom physical, emotional, mental, intellectual, and social disabilities have the right to obtain special education. Special Education also stated on Government Regulation No. 72 of 1991. Besides, Regulation of National Ministry of Education No. 70 of 2009 also concerns Inclusive Education for Students Who Have Abnormalities and Have Special Intelligent or Talents Potential (Ediyanto et al., 2017). The World Declaration on Education for All in the Jomtien Declaration stated that providing equality in education for persons with disabilities needs to be an integral part of the education system. The adoption in 1993 of the Standard Rules on Equalization of Opportunities for Persons with Disabilities provided for integration in public school, affirming that education for persons with disabilities should form an integral part of national educational planning, curriculum development, and school organization (Cera, 2015).

The implementation of inclusive education in Indonesia is stipulated in the Constituent of 1945 Article 31, Section 1 and Section 2 as stated in Act No. 23 of 2003 and emphasized in Minister of National Education Regulation (Permendik) No. 70 of 2009, special needs children's availability to attend public school, especially in early education. In reality, it has not covered all children with disabilities who did not get the education because of various factors and conditions in the field, specifically in rural areas. So, there is a good contribution from the central, province, and local government for implementing the Act. Besides, the government, teachers, parents, and community must build a contribution together (Rama, 2012).

The concept of Indonesian government policy on inclusive education is education for all, including students with disabilities guaranteed by the Constituent of 1945 Article 31 Section 1. Implementing inclusive education based on Indonesian philosophy with the motto Bhinneka Tunggal Ika 'Unity in Diversity, diversity in ethnicity, dialect, beliefs, and traditions is the nation's wealth that the nation's children should uphold. However, education for special needs students was not appropriately considered, which means that not all schools will accept students with disabilities. Various factors cause obstacles: educators, environmental accessibility, and exceptional guidance teachers' knowledge and skill to handle special needs students. 
Inclusive education is a national and international concern, which has provided a strong foundation and support in caring for persons with disabilities, such as The World Conference on Education for All. As a part of the integral education system, the Jomtien Conference adopted 1993 Standard Rules on equality for persons with disabilities provided integration in public schools (Cera, 2015).

\subsection{Characteristics of Inclusive Education}

Inclusive education has many characteristics grouped in several ways: relationship, ability, classroom seating arrangement, learning material, learning sources, and evaluation (Marthan, 2007). The relationship started in inclusive education characteristics is a warm and friendly attitude from the teachers. Then, what is meant by ability is the different abilities and backgrounds possed by teachers, students, and parents as companions. The classroom seating arrangement should be set varied. Learning material should contain various materials for all subjects. Learning sources come from children's daily activities; for example, the teacher asks students to bring cheap, easy-to-get learning media into the classroom for specific subjects. Last, regarding evaluation is the assessment of portfolios of students' work within a specific time.

Besides, a review of determinant factors can determine the inclusive education characteristics, including a robust framework, implementation based on local culture and context, continuous participation, and critical self-reflection (Saputra, 2016). In addition to the descriptions above, the characteristics of the inclusive class, including school conditions, welcoming attitudes, parental involvement, curriculum and instruction, teacher roles, classroom practices, assistance, and supporting material.

The determinants of inclusive characteristics reviewed robust frameworks such as values, beliefs, principles, and success indicators. In the implementation, the parties involved should not have conflicts related to those frameworks so that inclusive education does not easily collapse. Next, the implementation of local culture and context in the form of a solution to a problem should be developed locally by utilizing local sources so that the solution can last a long time. Finally, continuous participation and critical self-reflection are participatory monitoring involving all parties to keep inclusive education continuous because inclusive education is dynamic (Stubbs, 2008).

There are four meanings contained in the characteristics of inclusive education: 1) inclusive education is ways of responding to the individual children diversity, 2) inclusive education means finding ways to overcome barriers to learning, 3) inclusive education is defined as the opportunity for children especially children with disabilities to attend school, participate, and get meaningful learning outcomes in their lives, 4) inclusive education is intended for children who are classified marginal, exclusive, and need particular education service in learning (Ediyanto et al., 2017). 
Building community and establishing inclusive values can create indicators of cultural inclusion. The first indicator is building community indicators which consist of: welcoming everyone, cooperating staff, children help each other, staff and children respect each other, staff and parents/ carers collaborate, staff and governors work well together, the school is a model of democratic citizenship, the school encourages an understanding of the interconnections between people around the world, adults and children are responsive to a variety of ways of being a gender, the school, and local communities develop each other, staff link what happens in school to children's lives at home (Booth et al., 2011).

The second indicator is establishing inclusive values, including 1) the school develops inclusive values; 2) the school encourages respect for all human rights; 3) the school encourages respect for the integrity of planet earth; 4) inclusion is viewed as increasing participation for all; 5) expectations are high for all children; 6) children valued equally; 7) the school counters all forms of discrimination; 8) the school promotes non-violent interactions and resolutions to disputes, 9) the school encourages children and adults to feel good about themselves; 10) the school contributes to the health of children (Booth et al., 2011).

The importance of inclusive education's learning characteristics is that inclusive education is recently not optimal. University students with disabilities in Indonesia feel that segregation education is better than inclusive education because it fulfills their needs; meanwhile, inclusive education does not (Tributary, 2014). University students with disabilities stated that inclusive education had not fulfilled their needs because it is still new and had not been correctly applied (Triutari, 2014). Inclusive education has been implemented for quite a long time by the government and other parties. Still, the caretaker has not understood what inclusive education is. Those things become the importance of knowing and learning characteristics of inclusive education.

One of the meanings contained in the characteristics of inclusive education is that children get the chance to attend school, participate, and get the learning outcomes for their lives. Characteristic with those meaning is valid and gives a satisfactory result. Besides students with disabilities, the regular students also showed a supportive attitude by helping students with disabilities and did not discriminate against them (Riadin, Misyanto, \& Usop, 2017).

A study about early childhood inclusion described some valuable and least valuable characteristics programs. Results showed that participants value characteristics programs that 1) ensuring students with disabilities to active in all class routines and activities; 2) were considered as high-quality early childhood programs; 3) provided accommodation and adaptations to support the needs of students in learning; 4) employed teachers who are open to working with children with disabilities; 5) fostered collaboration between families, teachers, administrators, and other professionals; 6) facilitated self-reliance for students with disabilities; 7) has caring staffs (Hurley \& Horn, 2010). 
Meanwhile, characteristics program that least valuable is the program which 1) required students with disabilities to fulfill a series of criteria to participate in the program, 2) maintained classroom with $50 \%$ of students with disabilities; 3) expected students with disabilities to spend most of their daily activities based on teacher's direction (Hurley, \& Horn, 2010). Those least valuable program problems can be additional knowledge and consideration in arranging the characteristics program appropriate to Indonesia's condition and education needs.

\subsection{Aims of Inclusive Education}

Inclusive education policy aims to obtain equal education for special needs children with other normal children. Before the policy, the effort made was to prevent special needs students from dropping out by making teachers aware of having good services. However, that effort has not been fruitful and still needs strong legitimacy as a basis for resolving those problems (Hanjarwati \& Aminah, 2014). The inclusiveness values applied in school can introduce and respect diversity. The implementation of the inclusion program in Indonesia can foster children's social skills and self-confidence. Inclusive education is an educational program that accommodates all students in the same class based on their age and development (Tarnoto, 2016). It provides opportunities for children to interact, communicate, and adapt to their environment (Dewi, 2017). Inclusive education aims to provide opportunities for all children to optimize their potency and fulfill their learning needs.

The educational system consists of individuals, groups, identities, cultures, institutions, discourses, networks, history, relationships, etc. In other words, the education system is complex (Schuelka, \& Engsig, 2020). For example, marginalized students get an education rooted in remedial work skills and routine; meanwhile, privileged students get depth, breadth, and fulfillment with diversity and cognitive activities (Kozol, 2005; Rose, 2009). Those things also occurred with students with disabilities where they also burden with a "life skills" curriculum, which often had low quality and does not enrich their skills. The educational system was described above as qualification for all, socialization for most, and subjectification for the elite few are against the utility and purpose of schooling (Schuelka, \& Engsig, 2020).

Article 1 Minister of National Education Regulation No. 70 of 2009 stated that Inclusive education is implementing the educational system that provides opportunities to all students who have disabilities and intelligence/unique talents to participate in one environmental education with other regular students in general. Meanwhile, Article 2 Minister of National Education Regulation No 70 of 2009 stated the aims of inclusive education, including 1) providing most comprehensive opportunities to students who have physical, emotional, mental, and social or have intelligence potential or unique talent to have quality education appropriate to the needs and abilities; 2) creating the implementation of education that respect diversity and non-discriminatory for all students. 
Bronfenbrenner's ecological system views child development as a result of various interactions with their surrounding environment, which are different microsystems (family and school). One of them gives the attribution to the success and failures of an inclusive school. Children are also affected by:

1. Social interaction between two or more microsystems, such as the relation between family and school.

2. Relation between the microsystem and other systems does not include the ecosystem, such as the school and school's committee.

3. The environment where children live or macrosystems was influenced by cultures, institutions, areas, and others.

Schooling and knowledge learned were narrowly defined and over-valued, which made severe implications for inclusive education. Education's value or utility can only go far as the educational system respects individual child experiences and knowledge. From this perspective, it would be possible to analyze the important principles concerning the child's future. Students were also influenced by the macrosystem of the government (Dewi, 2017).

Inclusive education aims to provide opportunities for children with disabilities and learning barriers, such as the particular school location far away, working to help their parents, and other reasons, such as living in conflict areas or natural disasters. Many people hold that the authorities have an essential role in implementing inclusive schools, whether from a managerial or philosophical perspective (Dewi, 2017). The inclusive school aims to provide all students opportunities to optimize their potential and fulfill their learning needs through an inclusive education program (Dewi, 2017).

\section{CONCLUSION}

Inclusive education is an idea in educational decision-making that people can enjoy regardless of social status, topography, children with special needs, or other normal children to obtain proper and quality education for their lives. Inclusive education is a form of government's commitment to providing education rights for children with special needs. A legal basis guarantees the implementation of inclusive education in Indonesia based on the Constituent of 1945, the philosophy of the Indonesian nation, and legislation that has supported its implementation. The existence of regulations can maintain Indonesian citizens get the opportunity to obtain an education without any exceptions. For that to happen, it requires cooperation with the national components, including central, provincial, and local governments, educators, parents, and community, to achieve inclusive education. The characteristics of inclusive education, including all educational components, start from the goals and priorities of inclusive education, curricula, facilities, related parties, and other components. 
The characteristics of inclusive education must pay attention to the needs of children with disabilities. They should be flexible to achieve an education that runs well and lasts a long time. Through inclusive education, children with special education receive equal rights and educational service, including learning together with normal children. The inclusion program's success is fulfilling children's needs in the class, the absence of coercion, and the reduction of students' rights, which aims to implement the right to education and improve the social abilities of special needs children with other normal children.

\section{REFERENCES}

Booth, T., et al. 2011 . Index for Inclusion Developing Learning and Participation in Schools. CSIE.

Cera, R. (2015). Peraturan perundang-undangan nasional tentang pendidikan inklusif dan pendidikan khusus kebutuhan penyandang autisme dalam perspektif Pasal 24 CRPD. Dalam Melindungi Hak Penyandang Autisme di Bidang Pendidikan dan Pekerjaan (hlm. 79-108). Springer, Cham.

Dewi, N. K. (2017). Manfaat program pendidikan inklusi untuk aud. Jurnal Pendidikan Anak, 6(1), 12-19.

Ediyanto, E., Atika, I. N., Kawai, N., \& Prabowo, E. (2017). Inclusive education in Indonesia from the perspective of Widyaiswara in the Centre for Development and empowerment of teachers and education personnel of kindergartens and special education. IJDS: INDONESIAN JOURNAL OF DISABILITY STUDIES, 4(2), 104-116.

Engelbrecht, P., Savolainen, H., Nel, M., Koskela, T., \& Okkolin, M. A. (2017). Making meaning of inclusive education: Classroom practices in Finnish and South African classrooms. Compare: A Journal of Comparative and International Education, 47(5), 684-702.

Gasparyan, A. Y., Ayvazyan, L., Blackmore, H., \& Kitas, G. D. (2011). Writing a narrative biomedical review: considerations for authors, peer reviewers, and editors. Rheumatology international, 31 (11), 1409-1417.

Handayani, T., \& Rahadian, A. S. (2013). Peraturan perundangan dan implementasi pendidikan inklusif. Masyarakat Indonesia, 39(1), 149701.

Hanjarwati, A., \& Aminah, S. (2014). Evaluasi implementasi kebijakan pemerintah kota Yogyakarta mengenai pendidikan inklusi. INKLUSI Journal of Disability Studies, 1 (2), 221 248.

Herawati, N. I. (2016). Pendidikan Inklusif. EduHumaniora I Jurnal Pendidikan Dasar Kampus Cibiru, 2(1).

Hurley, J. J., \& Horn, E. M. (2010). Family and Professional Priorities for Inclusive Early Childhood Settings. Journal of Early Intervention, 32(5), 335-350. https://doi.org/10.1177/1053815110385650

Law of the Republic of Indonesia number 20 of 2003 concerning the national education system by the Ministry of National Education 
Lay Kekeh Marthan. (2007). Manajemen Pendidikan Inklusif. Jakarta: DIRJEN DIKTI

Miles, S., \& Singal, N. (2010). The Education for All and inclusive education debate: conflict, contradiction or opportunity? International journal of inclusive education, 14(1), 1-15.

Permendiknas, R. I. (2015). No. 70 Tahun 2009 tentang Pendidikan Inklusif bagi Peserta Didik yang Memiliki Kelainan dan Memiliki Potensi Kecerdasan dan/atau Bakat Istimewa, Jaringan Kementerian Riset, Teknologi dan Pendidikan Tinggi. Direktorat Pembin. Pendidik. Khusus dan Layanan Khusus Pendidik. Dasar.

Rama, R. (2012). Perlindungan Hukum Bagi Anak Berkebutuhan Khusus dengan Pelaksanaan Program Pendidikan Khusus/inklusif di Tinjau dari Berbagai Undang-Undang yang Berlaku. Jurnal Sosial Ekonomi Pembangunan, 2(4), 64-79.

Riadin, A., Misyanto, M., \& Usop, D. S. (2017). Karakteristik Anak Berkebutuhan Khusus di Sekolah Dasar Negeri (Inklusi) di Kota Palangka Raya. Anterior Jurnal, 17(1), 22-27.

Saputra, A. (2016). Kebijakan Pemerintah Terhadap Pendidikan Inklusif. Golden Age: Jurnal Ilmiah Tumbuh Kembang Anak Usia Dini, 1 (3), 1-15.

Schuelka, M. J., \& Engsig, T. T. (2020). On the question of educational purpose: complex educational systems analysis for inclusion. International Journal of Inclusive Education, 118.

Stubbs, S. (2008). Inclusive education. Where there are few resources. Oslo, The Atlas Alliance Publ.

Tarnoto, N. (2016). Permasalahan-permasalahan yang dihadapi sekolah penyelenggara pendidikan inklusi pada tingkat SD. Humanitas: Jurnal Psikologi Indonesia, 13(1), 50-61.

Triutari, I. (2014). Persepsi Mahasiswa Penyandang Disabilitas Tentang Sistem Pendidikan Segregasi Dan Pendidikan Inklusi (Deskrptif Kuantitatif Pada Penyandang Disabilitas di Universitas Negeri Padang). Jurnal Penelitian Pendidikan Khusus, 3(3). 